UDC 371.32

DOI https://doi.org/10.32840/1992-5786.2021.75-3.6

N. V. Yamshynska

Lecturer at the Department of Technical English № 2 National Technical University of Ukraine "Igor Sikorsky Kyiv Polytechnic Institute"

I. V. Meleshko

Senior Lecturer at the Department of Technical English № 2 National Technical University of Ukraine "Igor Sikorsky Kyiv Polytechnic Institute"

N. M. Kutsenok

Lecturer at the Department of Technical English № 2 National Technical University of Ukraine "Igor Sikorsky Kyiv Polytechnic Institute"

Ye. S. Kriukova

Associate Professor at the Department of Technical English № 2 National Technical University of Ukraine "Igor Sikorsky Kyiv Polytechnic Institute"

\title{
THE PROBLEM-BASED LEARNING APPROACH IS A WAY OF THE DEVELOPMENT OF COMMUNICATION SKILLS OF ESL STUDENTS OF ECOLOGY
}

The authors of the article conduct a historical overview of problem-based learning as a method, analyzing its goals and stages. The article is devoted to the study of the effectiveness of the implementation of problembased learning in order to improve and diversify the learning process. The authors emphasize the need to train specialists to solve practical problems and situations in the production through the formation of their skills in drawing up a plan and finding approaches to its implementation. The problem-based learning aims to develop critical thinking of students and reveal their creative potential. Analysis of recent publications has shown that experts agree that solving problems set for students in the classroom using methods and technologies of problem-based learning requires optimal independent work aimed at generating original ideas, forming the ability to make bold, non-standard decisions.

The article analyzes the features of teaching a foreign language on the basis of the introduction of one of the technologies of problem-based learning - role-playing and simulation exercises. The authors believe that roleplaying is designed to develop communication skills, which are one of the priority components of professional training. It is a method of active learning, during which students learn to make collective decisions, to reconcile their interests with the interests of the team in achieving common goals. The authors of the article conducted a study that showed a keen interest of foreign language teachers in the use of methods and technologies of problem-based learning in the classroom. The analysis of the received answers showed that problem-based learning can change the cognitive motivation of students when cognitive-motivational motives become central for students. The authors' research confirms the fact that foreign language teachers consider the problembased learning as a method that can make the foreign language teaching more exciting and productive.

Key words: problem-based learning, problem-solving methodology, effectiveness of problem-based learning, teaching method.

Problem statement. The European framework of key competences declares that the capacity to solve problems is representative for both the competence of learning how to learn and for the basic competencies in mathematics, sciences and technology, important being, in this sense, the identification of the adequate modalities of their development.

The problem-based learning approach is designed to encourage the development of these competences for students to perform abilities to combine their theoretical and experiential know-how while solving practical tasks at working surroundings. That's why the demand for in-depth understanding about the concept of problem-based learning approach and finding more effective ways of its implementation as a language teaching method for the development of students' communicative skills is extremely important nowadays.

Analysis of recent researches and publications. Educators nowadays express their strong interest to the problem of studying English for Special Purposes (ESP) at technical universities taking into account the importance of developing students' communicative skills through the problem-based learning approach. This approach attracts particular attention of the researchers from around the world because it 
possesses a great potential to make the studying and teaching process more exciting and productive. Zakaria considers that problem-based learning has various impacts in different disciplines of education [1]. Albino [2] and Ibrahim [3] in their studies have demonstrate the effectiveness of $\mathrm{PBL}$ approach and proved that due to the implementation of the PBL approach "there is an increase in average learning achievements of students".

Terry Barret suggested that "PBLis best understood not as a mere learning and teaching technique but as a total education strategy underpinned by philosophical principles" [4].

The following definition of the PBL approach made by Elaine and Karen Goh in their article fully reveals its main concept as a pedagogical approach that enables students to learn while engaging actively with meaningful problems [5].

The Problem-based learning approach has taken its important place in teaching English language and proved its efficiency in this discipline. The study confirmed that students increased their confidence in using the language when the PBL approach was applied in the language teaching process. Lytovchenko I., Lavrysh Y., Lukianenko V., Ogienko O. studied the possibilities of effective use of problembased tasks for teaching grammar. In addition, the study found that students focus their attention on grammatical forms due to a communicative context created with such tasks [6].

Review studies have shown that effective roleplay design is key for achieving actual motivation and learning effects in education. The positive impact of PBL seems to be on the generic skills and language skills, particularly on speaking. The greatest impact was on their condense in using the language. This is significant especially in language production, for instance in speaking, presentation and communication skills [7;8].

Communication or soft skills are considered to be the most important factor in private interactions at work and therefore as a determiner aimed to increase significantly employees' productivity. Recently, more and more education experts stress the importance of integrating them in learning process thoroughly, effectively and efficiently. The researchers are also convinced that students should be engaged in activities that bring together and cultivate mutual respect and understanding, a positive attitude, which will have a qualitatively new impact on becoming a responsible citizen of the country and the world. In this context the problem based learning approach has increased its popularity nowadays because it possesses some necessary instruments, which can be helpful in solving current issues the students faces today.

Formulating the goals of the article. To study the level of awareness of teachers about the main aspects of the problem-based learning approach and clarify their attitude to the role-play as a technique of the PBL approach.

Presentation of the main material. The fastpaced world today has a great influence on the way people view and realize various processes, which are happening around them. Modern demands, requests and challenges of every society contribute to the appearance of a new generation of young people who are ready to overcome the obstacles towards achieving both personal and professional goals. Students nowadays need advanced skills to be successful in the knowledge-based societies of today and for further professional development. Thus, during the period of studying at university students of the department of ecology should be armed with analytical skills and trained in thinking critically, acquire good communication skills, which certainly assure their future professional growth. A foreign language is a way for ESP students of ecology to extend both the barriers of the science and perspectives to carry out deep researches, which require the involvement of scientists from all around the world.

With the rapid development of modern technology, the deep integration between foreign language education and information communication technology (ICT) has transformed the traditional model of English language teaching and developed a new ecology.

The problem-based learning approach includes a range of techniques to solve the educational goals of ELS students subjected to teach them to apply their analytical thinking skills and develop selflearning abilities. A foreign language seems to be a good background and encourage ESP students in their future career development. With this objective in mind, teachers steadily try to find and become aware of ways to apply new methods, techniques and strategies to form and enhance necessary skills for students to be capable, confident and competent to meet novel professional performance standards. A role-play is considered as one of the most acceptable techniques of the problem-based learning approach.

The concept of PBL approach.

Howard Barrows, American physician and medical educator was one of the premiers to discuss theoretically the concepts of the problem based learning approach. The definition of PBL is a method of teaching that can be studied by students in small groups by the direction of a mentor or an "expert" [9].

In the PBL approach the problems are active in the process of learning. The objectives are to determine the objectives of the PBL application in the implication of the students in the collaboration and the development, which is equal to the previous studies of students and the development of the competencies of self-assessment and the implementation [10]. 
Terry Barrett sees the concept of the problem as a provoker of a liminal space. This liminal space is an in-between space between: 1) current levels of knowing and new levels of knowing; 2) habitual forms of professional action and forms of professional action new to the learner; 3 ) satisfaction with current identities and a desire to explore other possible identities [4].

To get significant learning outcomes from this approach it becomes extremely important to incorporate it in a variety of courses and disciplines that demands full reconsideration of the format of the learning process. Language learning as a discipline has undoubtedly enriched itself with a new effective approach when adopted PBL.

In such a model, the PBL approach complies with the following elements: the structure of the study program, the group assignment and evaluation. The other models are based on the project-based learning and the question of a subject or a problem [11]. The application of PBL comprises four main stages: the analysis of the problem, self-directed learning, the brainstorming and the validation of the solution [12].

Duch B.J., Groh S.E., Allen D.E. described the techniques used in the application of PBL and the development of specific competencies, including understanding the capacity to reflect critical manners, to analyze and to solve problems of complex real world problems, to evaluate appropriated formation; to work together, to dismantle the competencies of communication effects and to use the conceptions and intellectual competencies to apply constitutively [13; 14].

To achieve the main aims of our study we conducted a survey, which helped us to collect information about teachers' awareness of main aspects of PBL learning approach and their attitude to the method.

Data analysis allowed to learn more about the experience of teachers in using the PBL approach to the role play, aimed at developing students' analytical and critical thinking, but above all communication skills.

Participants: 30 teachers of the Department of English for Engineering of the National Technical University of Ukraine "Igor Sikorsky Kyiv Polytechnic Institute". Teachers participating in the current study taught ESP to students earning a bachelor's degree. The study was conducted in January 2021.

Before teachers were included in the study, they were asked to demonstrate and discuss the advantages and disadvantages of the methods and techniques they use to improve communication skills and provide ESL students in environmental studies with the necessary skills to interact effectively.

An anonymous questionnaire was then used. The questionnaire contained 12 questions, and respondents were asked to choose the answer that corresponded to their opinion. It took 20-25 minutes to complete the questionnaire.
The survey of 30 ESP teachers showed their awareness of the PBLapproach, its goals and features, advantages and disadvantages of implementation in the learning process. The fact that all teachers have experienced more or less this approach at lessons with ESL students confirmed the great importance of discussing issues related to the PBL approach.

More than half of ESP teachers (53\%) define the main goal of the PBL approach as an attempt to motivate students to solve real problems and solve realistic dilemmas. Not all teachers $(12 \%$ and $15 \%)$ have chosen options that define PBL as a studentcentered approach to learning and accordingly, as an approach aimed at developing self-learning skills through practice and reflection. More than a third of them agree that all options are the main goals of the PBL approach.

The majority of teachers $(72 \%)$ believe that thanks to the PBL approach, they increase the motivation of ESL students to learn, focusing learning on "real" scenarios. More than half of teachers believe that the PBL approach is useful for stimulating the development of valuable transferred (soft) skills that are useful throughout life: leadership, teamwork and communication.

These data confirm the fact that there is an urgent need to develop students' problem - solving skills and other most important skills for their future professional growth. Thus, the PBL approach greatly contributes to their formation as future specialists and help ESL students achieve their educational goals and learn to solve various problems.

The role of the teacher according to the majority $(96 \%)$ of respondents is to collaborate, supervise and repeat complex, deep and rigorous, studentcentered learning experiences. It is fully in line with the expectations of ESP teachers in the approach to meeting students' educational goals.

The results of the survey show that the PBL approach is often used by ESP teachers in their classes, as more than half of teachers $(60 \%)$ confirmed that they sometimes use the PBL approach as a teaching method, and a third of them ( $40 \%)$ often use it. There were no teachers who would rarely use this approach in their practice.

Improving English Language Proficiency includes reading, writing, speaking, and listening skills in English and the educational goals of ESP teachers at the classroom are to include methods of meaningful student participation in achieving these basic language skills. The majority of teachers (62\%) believe that the PBL approach has a great influence on the development of speaking, and about a quarter $(25 \%)$ of them chose writing and listening.

According to this survey, the role-plays and simulations are teaching methods for solving social and communicative problems. The majority of teachers $(88 \%)$ agree that they are more acceptable 
for the PBL approach and therefore consider them effective methods for implementing a problemoriented approach to learning and improving ESP students' oral communication skills. But not all teachers $(12 \%)$ expressed their uncertainty about this. More than half of the ESP teachers $(66 \%)$ think that the problem-based learning approach is rather effective in teaching vocabulary and grammar related to the field of professional interests.

The most effective way (chosen by $86 \%$ of teachers) of organization of the problem-based learning approach is as a work in small groups, because it potentially offers such learning environment which help students become self-directed learners and where they collaborate with other members of the group to achieve both individual and group learning goals.

Teachers' viewpoints on the most essential phrases of the problem-based learning approach for practice speaking skills acquisition are diverse. More than a half of the teachers $(56 \%)$ chose grouping and surveying, which in our opinion, seems quite sound, because it is as a phase, which increases student-student verbal interaction in the classroom and has a positive impact on the development of speaking skills. More than one third (26\%) gave their preferences to assessing and reflexing performance. The minority of ESP teachers pointed ( $26 \%$ and $14 \%$ correspondently) on introducing and announcing the problem, and monitoring and coaching.

The teachers, who took part in the survey, were offered to think and choose various soft skills developed due to the PBL approach and which will be useful for students in their further career development (critical thinking, collaborative, analytical, initiative. The majority of the teachers $(76 \%)$ believe that all these skills are needed to solve problems on a daily basis and those which are critical in the professional life.

The ESL students can face some problems before they will be successfully involved in the PBL approach. Approximately a half of the ESP teachers $(44 \%)$ chose a psychological barrier as one the main fear of the ESL students to speak a foreign language and consequently to acquire effective communicative skills. A third of the teachers $(32 \%)$ also think that poor language skills could hinder the ESL students' active participation in the PBL curriculums.

The PBL approach is extremely popular among the ESP teachers and they are tending to increase their awareness about the PBL approach.

Conclusions. The positions of researchers in the field of pedagogy create a new basis for understanding the steps for reorganization of the educational environment, which undoubtedly has to be based on the principles of the PBL approach. The effective educational process should be focused not only on mastering knowledge but also help improve students' readiness for an existence in a competitive society as well as should provide perspectives on what's possibly essential to survive and thrive today.

It should be mentioned that there is no only correct formula and approach to all the educational challenges of educational environment, but existing theoretical backgrounds and practical experience will surely improve the quality of teaching English for Special Purposes (ESP) at technical universities and help find effective strategies for building the 21st century communication skills in the context of lifelong education.

Consequently, the findings of the studies confirm the importance and priority of the 21st century communication skills for a person's existence in different environments.

\section{References:}

1. Zakaria M., Maat S., Khalid F. A Systematic Review of Problem Based Learning in Education. Creative Education. 2019. URL: https:// doi.org/10.4236/ce.2019.1012194.

2. Albino G. Improving speaking fluency in a taskbased language teaching approach: The case of EFL learners at PUNIV-Cazenga. SAGE Open, 2017. № 7 (2). P. 1-11. URL: https:// doi.org/10.1177/2158244017691077.

3. Ibrahim Yusri M., Yusof Rahimi M., Yaakob Faiz M., Othman Z. Communication Skills: Top Priority of Teaching Competency. International Journal of Learning Teaching and Educational Research. 2018. URL: https://www.ijlter.org/index.php/ijlter/ article/view/1559.

4. Barrett T. ANew Model of Problem-based learning: Inspiring Concepts, Practice Strategies and Case Studies from Higher Education. Maynooth : AISHE. 2017. 978-0-9935254-6-9 (electronic).

5. Elaine H.J. Yew, Karen Goh. Problem-Based Learning: An Overview of its Process and Impact on Learning. Health Professions Education. 2016. Vol. 2. Issue 2. P. 75-79. URL: https:// doi.org/10.1016/j.hpe.2016.01.004.

6. Lytovchenko I., Lavrysh Y., Lukianenko V., Ogienko O. How to teach grammar to adult ESP learners at technical university more communicatively: taskbased approach. Multidisciplinary Journal for Education, Social and Technological Sciences. 2020. № 7 (1). P. 54-71. URL: https://doi.org/10.4995/ muse.2020.12419.

7. Boyle E.A., Hainey T., Connolly T.M., Gray G., Earp J., Ott M., Pereira J. An update to the systematic literature review of empirical evidence of the impacts and outcomes of computer games and serious games. Computers \& Education. 2016. № 94. P. 178-192.

8. Clark D.B., Tanner-Smith E.E., Killingsworth S.S. Digital games, design, and learning: A systematic review and meta-analysis. Review of Educational Research. 2016. № 86. P. 79-122. 
9. Barrows Howard S. Problem-based learning in medicine and beyond: A brief overview. New Directions for Teaching and Learning. 1996. P. 3-12.

10.Sockalingam N., Rotgans J., Schmidt H. Assessing the Quality of Problems in ProblemBased Learning SIM. International Journal of Teaching and Learning in Higher Education. 2012. Vol. 24. № 1. P. 43-51

11. Barbosa da Silva A., Kruta de Araújo Bispo A., Goncalves Rodriguez D., lalyson F. Problembased learning. A proposal for structuring PBL and its implications for learning among students in an undergraduate management degree program / A. Barbosa da Silva, A. Kruta de Araújo Bispo, D. Goncalves Rodriguez and F. lalyson. Vasquez Universidade Federal da Paraíba - UFPB, João
Pessoa, Brazil HomeRevista de Gestão. 2018. Vol. 25. Issue 2. URL: https://www.emerald.com/ insight/content/doi/10.1108/REGE-03-2018-030/ full/html.

12. Massa Nicholas M. Problem-Based Learning (PBL): A Real-World Antidote to the Standards and Testing Regime. New England Journal of Higher Education. 2008. № 22, 4. P. 19-20.

13. Duch B.J., Groh S.E., Allen D.E. Why problembased learning? A case study of institutional change in undergraduate education. The power of problembased learning. Sterling, VA : Stylus, 2001. P. 3-11.

14.Chung Y., Yoo J., Kim S.W., Lee H., Zeidler D.L. Enhancing students' communication skills in the science classroom through socieoscientific issues. International Journal of Science and Mathematics Education. 2016. P. 1-27.

\footnotetext{
Ямшинська Н. В., Мелешко І. В., Куценок Н. М., Крюкова Є. С. Проблемний підхід до навчання як шлях розвитку комунікативних навичок студентів-екологів

Авторами статті проводиться історичний екскурс проблемного навчання як методу з аналізом
} його цілей та етапів. Історичні витоки проблемного навчання почали складатися як антипод традиційному або догматичному навчанню.

Стаття присвячена дослідженню ефективності впровадження проблемного навчання задля вдосконалення та урізноманітнення навчального процесу. Автори наголошують на необхідності підготовки спеціалістів до вирішення практичних проблем та ситуацій на виробництві через формування у них навичок складання плану та пошуку підходів до його реалізації. Саме проблемне навчання ставить перед собою цілі розвивати критичне мислення у студентів та розкривати їх творчий потенціал. Аналіз останніх публікацій показав, що фрахівці погоджуються з думкою про те, що вирішення завдань, що висуваються перед студентами на занятті з використанням методів та технологій проблемного навчання, вимагає від них оптимальної самостійної роботи, спрямованої на генерування оригінальних ідей, фрормування вміння приймати сміливі, нестандартні рішення.

У статmі аналізуються особливості викладання іноземної мови на основі впровадження однієї з технологій проблемного навчання, а саме рольової гри та симулятивних вправ. Автори вважають, що рольова гра покликана розвивати навички комунікації, які є одним із пріоритетних компонентів професійної підготовки фрахівців. Вона виступає методом активного навчання, під час якого студенти навчаються приймати колективні рішення, узгоджувати свої інтереси з інтересами колективу в досягненні загальних иілей. Авторами статті було проведено дослідження, яке виявило живий інтерес викладачів іноземної мови до застосування методів та технологій проблемного навчання в ході занять. Аналіз отриманих відповідей показав, що проблемне навчання здатне змінити пізнавальну мотивацію студентів, коли пізнавально-спонукальні мотиви стають для студентів центральними. Опитування підтверджує фракт, що викладачі іноземної мови розглядають проблемне навчання як метод, який здатен зробити викладання іноземної мови більш захоплюючим і продуктивним. Проте завдання викладача полягає в опануванні методологією проблемного навчання. Для того щоб студенти могли успішно вирішити проблему, процес постановки проблеми має вирішальне значення. Саме тому автори наголошують на необхідності постійного вдосконалення та пошуку нових шляхів реалізації інноваційних технологій у своїй роботі.

Ключові слова: проблемне навчання, методологія вирішення проблем, ефрективність проблемного навчання, метод навчання. 